\title{
Degarelix and its therapeutic potential in the treatment of prostate cancer
}

\author{
Christian Doehn \\ Martin Sommerauer \\ Dieter Jocham \\ Department of Urology, University \\ of Lübeck Medical School, Lübeck, \\ Germany
}

\begin{abstract}
Degarelix is a gonadotropin-releasing hormone $(\mathrm{GnRH})$ antagonist for the treatment of patients with prostate cancer in whom hormonal therapy is indicated. Two phase II trials and one phase III have been published as full papers in the literature. In the dose-finding phase II studies an initial dose of $240 \mathrm{mg}$ degarelix sc followed by a monthly injection of $80 \mathrm{mg}$ or $160 \mathrm{mg}$ degarelix sc was sufficient to keep testosterone levels $\leq 0.5 \mathrm{ng} / \mathrm{ml}$. In a phase III trial it was demonstrated that degarelix was not inferior (in terms of testosterone suppression and prostate-specific antigen [PSA] decline) compared to standard hormonal therapy, ie, a GnRH agonist such as leuprolide. In fact, degarelix was associated with a faster testosterone suppression and PSA decline than leuprolide. Adverse events such as injection site reactions ( $40 \% \mathrm{vs}<1 \%$ ) and chills (4\% vs $0 \%$ ) were more commonly associated with degarelix. Also, degarelix is currently only available as one-month depot whereas in daily practice three-month depots (of GnRH agonists) are the preferred regimen. However, degarelix was recently approved by the US Food and Drug Administration for the treatment of advanced prostate cancer.
\end{abstract}

Keywords: prostate cancer, hormonal therapy, GnRH antagonist, degarelix, testosterone, flare

\section{Introduction}

Prostate cancer is the most common malignancy in the US and in western Europe with an estimated 186,320 newly diagnosed cases in 2008 in the US and 28,660 men who died of prostate cancer in the US (incidence-mortality ratio of 6.5). ${ }^{1}$

The therapeutic options available predominantly depend on cancer stage as well as patient age and co-morbidity. In organ-confined prostate cancer the treatment is radical prostatectomy, external beam radiotherapy, or brachytherapy. In this stage of the disease, therapy is with curative intention and patients have an excellent prognosis. ${ }^{2}$ Active surveillance or watchful waiting are also options in patients with low risk organ-confined prostate cancer (ie, clinical stage T1c-2a and Gleason score 6 and prostate-specific antigen (PSA) less than 10 and less than 33\% of prostate biopsies positive for cancer). ${ }^{3}$ Primary androgen deprivation therapy might also be an option but without curative intention. ${ }^{4}$ However, androgen deprivation therapy is not regarded as standard in patients with localized prostate cancer. ${ }^{5}$

In metastatic prostate cancer and/or in patients who are not able to undergo the above treatment options because of their age and/or co-morbidity, the standard of care is androgen deprivation therapy. ${ }^{6}$ Watchful waiting may also be applied under the latter circumstances.

Huggins first described the effect of castration on prostate cancer in $1941 .^{7}$ This was the basis for the finding that prostate cancer cells need androgens for their growth. Without the receptor-mediated stimulus of androgens prostate cancer cells undergo apoptosis. ${ }^{8,9}$ Androgens are synthesized in the testes (95\%) and in the adrenal glands $(5 \%)$. The androgen synthesis underlies a hormonal regulation by the hypothalamicpituitary-gonadal axis in a negative feedback manner. 
Based on these findings, lowering testosterone levels either medically or surgically and/or blockade of the androgen receptor represents the principal mechanism of androgen deprivation therapy of prostate cancer. ${ }^{10}$ Surgical castration can be done by bilateral orchiectomy. This is an effective procedure and not associated with relevant complications. The disadvantages are the possible negative psychological effects and the fact that no intermittent androgen deprivation therapy can be applied. ${ }^{11}$

Similar effects can be achieved by suppression of the gonadotropins luteinizing hormone (LH) and folliclestimulating hormone (FSH) with gonadotropin-releasing hormone (GnRH) agonists (eg, buserelin, goserelin, leuprolide, triptorelin) that desensitize the pituitary gland. This leads to a suppression of the LH synthesis and secretion followed by decreased stimulus for testosterone synthesis within the testicles. Another medical manipulation of this hormonal regulation can be achieved by blocking the androgen receptor with steroidal antiandrogens (eg, cyproterone acetate) or nonsteroidal antiandrogens (eg, bicalutamide, flutamide).$^{10}$ However, the effect from androgen receptor blockade is considered to be less effective compared to LH-releasing hormone (LHRH) agonists (at least in metastatic disease).

Blocking the GnRH receptor with an antagonist in the pituitary gland is obviously the most logical way to achieve a fast and reversible decrease of $\mathrm{LH}, \mathrm{FSH}$, and testosterone without any clinical flare. For a long time, however, GnRH antagonists showed relevant release of histamine from mast cells with acute systemic allergic reactions. ${ }^{12}$ Another constriction for clinical usefulness was limited solubility. ${ }^{13}$

Degarelix (Ferring Pharmaceuticals, Kiel, Germany) is the second GnRH antagonist that has been tested in a phase III trial. ${ }^{14}$ Degarelix has also proven its potential in achieving testosterone suppression without any evidence of clinical flare. Additionally, no acute systemic allergic reactions were observed in patients treated with degarelix. ${ }^{15-17}$

This review aims to summarize phase II and III trials on degarelix for the treatment of patients with prostate cancer.

\section{Efficacy}

\section{Phase II dose-finding studies}

There are four phase II dose-finding studies in the literature. Two of them are only available in abstract form and the remaining are full publications.

Data from a randomized phase II trial were presented by Weston and colleauges at the SIU congress in $2004 .{ }^{18}$ In this trial, 129 patients (age 55-87 years) with prostate cancer of all stages who were candidates for androgen deprivation therapy were treated in three different dose regimens between $20 \mathrm{mg}$ and $80 \mathrm{mg}$ (arm A: degarelix 80/80/40 (ie, $80 \mathrm{mg}$ on day $0,80 \mathrm{mg}$ on day 3 , and $40 \mathrm{mg}$ on day 28 ); arm B: degarelix 80/-/20; arm C: degarelix 40/40/40) administered on day 0,3 , and 28 , respectively, and every 28 days thereafter. At baseline the median PSA level was $61 \mathrm{ng} / \mathrm{ml}$. In this study, arm A was the most effective in achieving castration levels. At six-month follow-up $87.5 \%, 72.2 \%$, and $58.8 \%$ of patients in arms $\mathrm{A}, \mathrm{B}$, and $\mathrm{C}$ had a testosterone $\leq 0.5 \mathrm{ng} / \mathrm{ml} .^{18}$

Results from a phase II multicenter, randomized doseescalating study testing degarelix in patients with prostate cancer were presented by Tammela and colleagues at the EAU congress in $2005 .{ }^{19}$ In this trial, 172 patients (age 48-89 years) with prostate cancer were included. These patients had a baseline median testosterone of $4.16 \mathrm{ng} / \mathrm{ml}$ and a median PSA of $38 \mathrm{ng} / \mathrm{ml}$. Patients with metastatic prostate cancer (31\%), locally advanced prostate cancer (36\%), and localized prostate cancer (26\%) were included. Degarelix was administered sc at doses between $120 \mathrm{mg}$ and $320 \mathrm{mg}$. The concentrations varied between $20 \mathrm{mg} / \mathrm{ml}$ and $60 \mathrm{mg} / \mathrm{ml}$. The efficacy could be evaluated in 169 patients at day 3 and day 28 by measurement of testosterone and PSA. Degarelix showed a dose- and concentration-dependent effect. A dose of $240 \mathrm{mg}(40 \mathrm{mg} / \mathrm{ml})$ resulted in castration (defined as testosterone $\leq 0.5 \mathrm{ng} / \mathrm{ml}$ ) in $96 \%$ of the patients and was the most effective regimen. ${ }^{19}$

Two phase II studies have been conducted to evaluate the efficacy of degarelix in different doses regimen in long-term follow-up. ${ }^{20,21}$

One open label, randomized phase II study with a starting dose of $200 \mathrm{mg}$ degarelix sc and a monthly administration of $60 \mathrm{mg}$ degarelix sc (200/60, arm A) or $80 \mathrm{mg}$ degarelix sc (200/80, arm B) was conducted in North America. ${ }^{20}$ In total, 127/176 screened patients with prostate cancer were enrolled. Patients had a median age of 76 years (range 47-93 years). Inclusion criteria were testosterone $>2.2 \mathrm{ng} / \mathrm{ml}, \mathrm{PSA}>2 \mathrm{ng} / \mathrm{ml}$, and Eastern Cooperative Oncology Group (ECOG) score of 2 or less.

The primary endpoint was the proportion of patients with serum testosterone $\leq 0.5 \mathrm{ng} / \mathrm{ml}$ at all monthly measurements throughout the entire study period (ie, 12 months) and the proportion of patients with testosterone $\leq 0.5 \mathrm{ng} / \mathrm{ml}$ at all monthly measurements throughout the entire study period for those patients who had a testosterone $\leq 0.5 \mathrm{ng} / \mathrm{ml}$ after one month. Secondary endpoints included:

- The proportion of patients with a testosterone $\leq 0.5 \mathrm{ng} / \mathrm{ml}$ at day 3

- Time to $50 \%$ and $90 \%$ reduction in PSA 
- Time to PSA progression (defined as PSA increase of $50 \%$ or more from nadir and at least $5 \mathrm{ng} / \mathrm{ml}$ on two consecutive visits at least two weeks apart)

- Pharmacodynamic parameters such as testosterone, PSA, dihydrotestosterone (DHT), LH, and FSH over time.

There were 23 patients with protocol violations, 16 withdrawals due to inadequate testosterone suppression, six withdrawals due to adverse events, and 18 withdrawals due to other reasons. Therefore, $87 / 127$ patients (69\%) completed the study. Arm A comprised of 42 patients and arm B of 45 patients without differences with regard to demographics and baseline characteristics. Median PSA at baseline was $13.4 \mathrm{ng} / \mathrm{ml}$ (25th-75th percentile: $6.8-25.7 \mathrm{ng} / \mathrm{ml})$. Median testosterone level at baseline was $4.13 \mathrm{ng} / \mathrm{ml}$ (25th-75th percentile: $3.06-5.11 \mathrm{ng} / \mathrm{ml}$ ). Tumor stages were localized in $43 \%$, locally advanced in $11 \%$, metastatic in $19 \%$, and not classifiable in $28 \%$ of patients. The Gleason score was $2-4$ in $5 \%, 5-6$ in $32 \%$, and $7-10$ in $63 \%$ of cases, respectively.

In this study no testosterone surge was observed. At day $3,89 \%$ of all patients had a testosterone $\leq 0.5 \mathrm{ng} / \mathrm{ml}$ without a statistically significant difference between both groups (Table 1). After one month $88 \%$ of all patients had a testosterone $\leq 0.5 \mathrm{ng} / \mathrm{ml}$ ( $93 \%$ of patients in arm A compared to $83 \%$ of patients in arm $\mathrm{B} \mathrm{p}=0.073$ ). The authors concluded that the starting dose was too low to achieve the predefined efficacy success criterion of $95 \%$ of patients with a testosterone level $\leq 0.5 \mathrm{ng} / \mathrm{ml}$. This was the rationale to test $240 \mathrm{mg}$ as a starting dose in subsequent trials. Only $86 \%$ of patients in arm $\mathrm{A}$ and $77 \%$ of patients in arm B remained with their testosterone $\leq 0.5 \mathrm{ng} / \mathrm{ml}$ during the entire study period ( $\mathrm{p}=$ not significant, exact $\mathrm{p}$ value not given in publication). However, the majority of patients who had a testosterone $\leq 0.5 \mathrm{ng} / \mathrm{ml}$ after one month remained within this range for the entire study period (93\% of patients in arm A compared to $98 \%$ of patients in $\operatorname{arm} \mathrm{B} ; \mathrm{p}=0.669)$. A PSA decline of $50 \%$ and $90 \%$ was achieved after 14 and 56 days in both treatment groups and a median reduction of $96 \%$ was documented after 12 months. ${ }^{20}$

The second study was conducted in Europe and South Africa and screened 216 patients with prostate cancer of whom 189 were randomized and 187 received study medication. ${ }^{21}$ Median age was 72 years (range $52-93$ years). The inclusion criteria were similar to that in the North American study. ${ }^{20}$ Patients were randomized to six different dose regimens with an initial dosage of $200 \mathrm{mg}$ degarelix or $240 \mathrm{mg}$ degarelix followed by monthly maintenance dosage of degarelix $80 \mathrm{mg}$, degarelix $120 \mathrm{mg}$, or degarelix $160 \mathrm{mg}$ (groups 200/80, 200/120, 200/160, 240/80, 240/120, $240 / 160)$, respectively. In all groups, a concentration of $40 \mathrm{mg} / \mathrm{ml}$ degarelix was used. Thus, the sc injected volume varied between $2 \mathrm{ml}$ and $4 \mathrm{ml}$.

Table I Published phase II and III trials on degarelix and prostate cancer: Efficacy

\begin{tabular}{|c|c|c|c|}
\hline Author & Patients & Study design & Results \\
\hline Gittelman $^{20}$ & $N=127$ & $\begin{array}{l}\text { Phase II } \\
\text { Efficacy and safety of degarelix with } \\
\text { a starting dose of } 200 \mathrm{mg} \text { followed } \\
\text { by monthly maintenance doses of } 60 \mathrm{mg} \\
\text { or } 80 \mathrm{mg} \text { for one year. }\end{array}$ & $\begin{array}{l}\text { Testosterone suppression: } \\
88 \% \text { after one month, } 93 \% \text { and } 98 \% \\
(60 \mathrm{mg} \text { and } 80 \mathrm{mg}) \text { after one year. } \\
\text { PSA response: } \\
\text { Median reduction } 96 \% \text { after one year }\end{array}$ \\
\hline van Poppel $^{21}$ & $N=187$ & $\begin{array}{l}\text { Phase II } \\
\text { Efficacy and safety of degarelix with a } \\
200 \mathrm{mg} \text { or } 240 \mathrm{mg} \text { starting dose followed } \\
\text { by monthly maintenance doses of } 80 \mathrm{mg} \text {, } \\
120 \mathrm{mg} \text {, or } 160 \mathrm{mg} \text { for one year. }\end{array}$ & $\begin{array}{l}\text { Testosterone suppression: } \\
86 \% \text { ( } 200 \mathrm{mg} \text { ) vs } 95 \% \text { ( } 240 \mathrm{mg} \text { ) after one } \\
\text { month, } 92 \% \text { ( } 80 \mathrm{mg}), 96 \% \text { (120 mg), 100\% } \\
\text { (160 mg) after one year. } \\
\text { PSA response: } \\
\text { Median reduction } 97 \%-98 \% \text { after one year }\end{array}$ \\
\hline $\mathrm{Klotz}^{14}$ & $N=610$ & $\begin{array}{l}\text { Phase III } \\
\text { Efficacy and safety of degarelix with } \\
\text { a starting dose of } 240 \mathrm{mg} \text { followed } \\
\text { by monthly maintenance dose of } 80 \mathrm{mg} \\
\text { or } 160 \mathrm{mg} \text { vs leuprolide } 7.5 \mathrm{mg} \text { monthly. }\end{array}$ & $\begin{array}{l}\text { Testosterone suppression: } \\
97.2 \%, 98.3 \% \text { in patients treated with } \\
\text { degarelix ( } 240 / 80 \mathrm{mg}, 240 / 160 \mathrm{mg}) \text { and } \\
96.4 \% \text { in patients treated with leuprolide } \\
\text { after one year. } \\
\text { PSA response: } \\
\text { PSA decline from baseline was significant } \\
\text { faster in the degarelix groups than } \\
\text { with leuprolide, PSA values not given in } \\
\text { publication. }\end{array}$ \\
\hline
\end{tabular}

Abbreviation: PSA, prostate-specific antigen. 
Primary endpoint was to determine the proportion of patients with testosterone $\leq 0.5 \mathrm{ng} / \mathrm{ml}$ after one month and every month thereafter. Results were given for the intention-to-treat (ITT) population ( $\mathrm{n}=187$ patients). Secondary endpoints were the proportion of patients with testosterone $\leq 0.5 \mathrm{ng} / \mathrm{ml}$ up to one year for those patients with testosterone $\leq 0.5 \mathrm{ng} / \mathrm{ml}$ after one month, the proportion of patients with testosterone level $\leq 0.5 \mathrm{ng} / \mathrm{ml}$ at day 3, times to reach $50 \%$ and $90 \%$ reduction in PSA, time to reach PSA progression (defined as a PSA increase $\geq 50 \%$ and at least $5 \mathrm{ng} / \mathrm{ml}$ compared to nadir on two consecutive visits at least two weeks apart), and pharmacodynamic parameters (serum testosterone, DHT, PSA, LH, and FSH over time).

There were four patients with protocol violations, 16 withdrawals due to inadequate testosterone suppression, 13 withdrawals due to adverse events, and 13 withdrawals due to other reasons. Therefore, $147 / 187$ patients (78\%) completed the trial. The median testosterone level at baseline was $4.13 \mathrm{ng} / \mathrm{ml}$ (25th-75th percentile: $3.37-5.19 \mathrm{ng} / \mathrm{ml})$ and median PSA at baseline was $27.6 \mathrm{ng} / \mathrm{ml}$ (25th-75th percentile: $12-55 \mathrm{ng} / \mathrm{ml}$ ). Tumor stages were localized in $22 \%$, locally advanced in $32 \%$, metastatic in $19 \%$, and not classifiable in $22 \%$ of patients. The Gleason score was $2-4$ in $19 \%, 5-6$ in $41 \%$, and $7-10$ in $39 \%$ of cases, respectively. There were no differences between the six groups except for median PSA which was $15.2 \mathrm{ng} / \mathrm{ml}$ in the $200 / 80$ treatment group compared to $35.3 \mathrm{ng} / \mathrm{ml}$ in the $240 / 120$ treatment group.

No testosterone surge was observed. At day 3, $88 \%$ of patients with degarelix $200 \mathrm{mg}$ as initial dose and $92 \%$ of patients with degarelix $240 \mathrm{mg}$ as initial dose had testosterone levels $\leq 0.5 \mathrm{ng} / \mathrm{ml}$ (Table 1). After one month a significant higher proportion of patients who received degarelix $240 \mathrm{mg}$ vs degarelix $200 \mathrm{mg}$ as initial dose had a testosterone $\leq 0.5 \mathrm{ng} / \mathrm{ml}$ (95\% vs $86 \%$; $\mathrm{p}=0.048)$. With different maintenance doses (degarelix $80 \mathrm{mg}$ vs $120 \mathrm{mg}$ vs $160 \mathrm{mg}$ ) testosterone level remained equal or below $0.5 \mathrm{ng} / \mathrm{ml}$ in $92 \%, 96 \%$ and $100 \%$ of patients until the end of the study. The median time to reach a PSA decline of $50 \%$ and $90 \%$ was 14 and 56 days. The only exception was the $200 / 80$ group in whom the $90 \%$ PSA decline was reached after 84 days. After one year the median PSA reduction was $97 \%-98 \% .^{21}$

\section{Phase III study}

Recently, a randomized, open-label, three-arm phase III study to evaluate the efficacy of degarelix versus leuprolide for achieving and maintaining testosterone suppression in patients with prostate cancer over a period of one year was published. ${ }^{14}$
Men aged 18 years or older with histological confirmed adenocarcinoma of the prostate of all stages were included. Patients must have had a PSA of $2 \mathrm{ng} / \mathrm{ml}$ or more, a testosterone of $1.5 \mathrm{ng} / \mathrm{ml}$ or more, and an ECOG of 0-2. Previous or current androgen deprivation therapy was not allowed except some neoadjuvant or adjuvant androgen deprivation therapy of less than six months duration and discontinuation six months or longer ago. Patients considered for therapy with curative intention were excluded. Between February 2006 and October 2007, 807 patients were screened. Of these, 620 patients were randomized and 610 patients received the study medication. Median age was 72 years (range 50-98 years), median PSA was $19 \mathrm{ng} / \mathrm{ml}$ (25th-75th percentile: $8.7-57 \mathrm{ng} / \mathrm{ml}$ ), and median testosterone was $3.93 \mathrm{ng} / \mathrm{ml}$ (25th-75th percentile: $2.89-5.1 \mathrm{ng} / \mathrm{ml})$.

Patients were randomized to one of the three following treatment arms: Arm A: degarelix $240 \mathrm{mg}$ as initial dosage $(2 \times 3 \mathrm{ml} \mathrm{sc})$ followed by $80 \mathrm{mg}(1 \times 4 \mathrm{ml} \mathrm{sc})$ monthly; Arm B: degarelix $240 \mathrm{mg}(2 \times 3 \mathrm{ml} \mathrm{sc})$ as initial dosage followed by $160 \mathrm{mg}(1 \times 4 \mathrm{ml} \mathrm{sc})$ monthly; Arm C: leuprolide $7.5 \mathrm{mg}$ $(1 \times 1 \mathrm{ml}$ intramuscularly [im]) monthly. A clinical flare protection with bicalutamide $(1 \times 50 \mathrm{mg}$ per os [po] $)$ was allowed at the discretion of the investigator.

The primary endpoint of the study was the cumulative probability of testosterone suppression $\leq 0.5 \mathrm{ng} / \mathrm{ml}$ from 28-364 days at monthly measurements. The trial also had 14 secondary endpoints:

- Proportion of patients with testosterone surge during the first two weeks of treatment

- Proportion of patients with testosterone levels of $\leq 0.5 \mathrm{ng} / \mathrm{ml}$ at day 3

- Probability of testosterone $\leq 0.5 \mathrm{ng} / \mathrm{ml}$ from 56-364 days

- Probability of insufficient testosterone response (defined as one or more testosterone levels $\geq 1 \mathrm{ng} / \mathrm{ml}$ or two or more testosterone measurements $\geq 0.5 \mathrm{ng} / \mathrm{ml}$ ) from 28-364 days

- Frequency and size of testosterone increases at 255 days and/or 259 versus testosterone level at 252 days

- Serum levels testosterone, LH, FSH, and PSA over time

- Percentage change in PSA from baseline to 14-28 days

- Time to PSA failure (PSA increase $\geq 50 \%$ from nadir and $\geq 5 \mathrm{ng} / \mathrm{ml}$ on two consecutive occasions at least two weeks apart)

- Degarelix concentration over the first month and through levels at 308 and 336 days

- Frequency and severity of adverse events

- Clinically significant changes in laboratory values

- Changes in electrocardiogram and vital signs

- Quality of life on 0,28, 84, 168, and 364 days 
- Hot flash frequency and hot flash score daily from study start until 354 days.

The primary endpoint (ie, testosterone levels $\leq 0.5 \mathrm{ng} / \mathrm{ml}$ from 28-364 days) was reached (in both ITT and per-protocol analyses) and thus it was demonstrated that degarelix (240/80 and 240/160) was noninferior to leuprolide (Table 1). The number of responders in the degarelix 240/80 and $240 / 160$ as well as the leuprolide $7.5 \mathrm{mg}$ group were 202/207 patients (97.2\%), 199/202 patients (98.3\%), and 194/201 patients $(96.4 \%)$.

One of the secondary endpoints was the proportion of patients with a testosterone level $\leq 0.5 \mathrm{ng} / \mathrm{ml}$ at day 3 . As expected, $96.1 \%$ and $95.5 \%$ of patients treated with degarelix 240/80 and 240/160 had a testosterone level $\leq 0.5 \mathrm{ng} / \mathrm{ml}$ at day 3 . In contrast, none of the patients in the leuprolide group achieved this result. In fact, the testosterone level in the latter group increased by $65 \%$ (median level $6.3 \mathrm{ng} / \mathrm{ml}$, $\mathrm{p}<0.001)$. From days 28-364 the median testosterone levels were $0.082 \mathrm{ng} / \mathrm{ml}$ and $0.088 \mathrm{ng} / \mathrm{ml}$ in the degarelix groups and $0.078 \mathrm{ng} / \mathrm{ml}$ in the leuprolide group.

In the leuprolide group 23/201 (11\%) patients received a concomitant medication with bicalutamide for clinical flare protection defined as testosterone increase $>15 \%$ from baseline on any two days during the first two weeks. In this subgroup 17/23 (74\%) had a testosterone surge and 144/178 $(81 \%)$ of the patients in the leuprolide group who did not receive bicalutamide had a testosterone surge and none of the patients treated with degarelix had a testosterone surge.

At days 14 and 28, PSA declined from baseline by $64 \% / 85 \%$ and $65 \% / 83 \%$ in the $240 / 80$ and $240 / 160$ degarelix groups compared to $18 \% / 68 \%$ in the leuprolide group. These differences in PSA reduction were statistically significant $(\mathrm{p}<0.001)$. Insufficient response to treatment was evident in 12 patients: four and two patients (1.9\% and $1 \%)$ in the degarelix 240/80 and 240/160 groups as well as six patients $(3 \%)$ in the leuprolide $7.5 \mathrm{mg}$ group. ${ }^{14}$

\section{Safety}

The analysis of phase I, II, and III trials demonstrates that there is no evidence for allergic reaction associated with the treatment with degarelix which was the major disadvantage for clinical use of former GNRH antagonists like abarelix. ${ }^{14,20-22}$

\section{Results from phase II trials}

In the North American phase II trial including 127 patients with prostate cancer (of whom 87 patients completed the study) adverse events occurred in $87 \%$ of patients receiving degarelix $200 / 80$ and $81 \%$ of patients receiving degarelix 200/60 (Table 2). ${ }^{20}$ Most adverse events were mild to moderate but the exact number of mild, moderate, and severe adverse events was not given. However, $13 \%$ of patients had at least one severe adverse event. The most frequent adverse events were hot flashes

Table 2 Published phase II and III trials on degarelix and prostate cancer: adverse events

\begin{tabular}{|c|c|c|c|}
\hline Adverse event & $\begin{array}{l}\text { Gittelman }^{20} \text { (Phase II) } \\
\text { degarelix } 200 / 80 \text { vs } 200 / 60\end{array}$ & $\begin{array}{l}\text { van } \text { Poppel }^{21} \text { (Phase II) } \\
\text { degarelix } 200 / 80 \text { vs } 200 / / 20 \text { vs } 200 / / 60 \\
\text { vs } 240 / 80 \text { vs } 240 / / 20 \text { vs } 240 / / 60\end{array}$ & $\begin{array}{l}\text { Klotz }^{14} \text { (Phase III) } \\
240 / 80 \text { vs } 240 / / 60 \text { vs leuprolide } 7.5\end{array}$ \\
\hline Any adverse event (\%) & $87 / 81$ & $57 / 66 / 75 / 63 / 73 / 67$ & 79/83/78 \\
\hline Hot flash (\%) & $38 / 48$ & $47 / 25 / 31 / 37 / 27 / 33$ & $26 / 26 / 21$ \\
\hline Fatigue (\%) & $16 / 23$ & $7 / 3 / 6 / 10 / 3 / 7$ & $3 / 6 / 6$ \\
\hline Injection site pain (\%) & $6 / 8$ & $3 / 9 / 0 / 13 / 9 / 7$ & Not given \\
\hline Injection site reaction (\%) & Not given & Not given & $35 / 44 / 1$ \\
\hline Weight increase (\%) & $6 / 6$ & $0 / 9 / 13 / 13 / 9 / 7$ & $9 / 11 / 12$ \\
\hline Back pain (\%) & $3 / 9$ & $7 / 9 / 6 / 3 / 6 / 3$ & $6 / 6 / 8$ \\
\hline Nasopharyngitis (\%) & $11 / I 1$ & Not given & Not given \\
\hline Dizziness (\%) & $11 / 9$ & Not given & Not given \\
\hline Arthralgia (\%) & $6 / 6$ & Not given & $5 / 3 / 9$ \\
\hline Constipation (\%) & $6 / 6$ & Not given & $3 / 5 / 5$ \\
\hline Hypertension (\%) & $6 / 6$ & Not given & $6 / 7 / 4$ \\
\hline Urinary tract infection (\%) & Not given & $7 / 6 / 6 / 7 / 6 / 3$ & $5 / 1 / 9$ \\
\hline ALT increase (\%) & Not given & $10 / 3 / 9 / 0 / 3 / 3$ & $10 / 8 / 5$ \\
\hline Cough (\%) & Not given & $7 / 3 / 6 / 0 / 3 / 7$ & Not given \\
\hline Diarrhea (\%) & Not given & $3 / 9 / 6 / 0 / 3 / 7$ & Not given \\
\hline Chills (\%) & Not given & Not given & $3 / 5 / 0$ \\
\hline
\end{tabular}

Abbreviation: ALT, alanine aminotransferase. 
in $38 \%$ and $48 \%$ of patients followed by fatigue in $16 \%$ and $23 \%$ of patients. Nasopharyngitis (11\% vs $11 \%)$ and dizziness $(11 \%$ vs $9 \%$ ) were other adverse events. Pain at the injection site was evident in $6 \%$ and $8 \%$ of patients treated with degarelix. ${ }^{20}$

In the European and South African phase II trial including 187 patients with prostate cancer (of whom 147 patients completed the study) six different dose regimens of degarelix (200/80, 200/120, 200/160, 240/80, 240/120, and 240/160) were tested. ${ }^{21}$ Adverse events occurred in $57 \%$ to $75 \%$ of patients within these groups (Table 2). Most adverse events were mild to moderate but the exact number of mild, moderate, and severe adverse events was not given. However, $11 \%$ of patients had at least one severe adverse event. Hot flashes of mild to moderate intensity were documented in $33 \%$ (range $27 \%-47 \%$ ) of cases. Fatigue occurred in $6 \%$ (range $3 \%-10 \%$ ) of patients and weight increase in $9 \%$ (range $0 \%-13 \%$ ) of patients. An increase of alanine aminotransferase was measured in 9\% (range 3\%-10\%) of patients. Pain at the injection site was evident in $10 \%$ (range $0 \%-13 \%$ ) of patients treated with degarelix. ${ }^{21}$

In the North American phase II trial, three patients (2\%) died and another 11 patients $(6 \%)$ died in the European and South African phase II trial. None of the reported deaths were considered to be related to degarelix..$^{20,21}$

\section{Results from a phase III trial}

In the randomized phase III trial adverse event were reported in $81 \%$ of $330 \%$ patients of the pooled degarelix groups and in $78 \%$ of $156 \%$ patients of the leuprolide group (Table 2$).{ }^{14}$ The intensity of all reported adverse events in the pooled degarelix group versus the leuprolide group was mild in $283(69 \%)$ versus $138(69 \%)$ patients, moderate in $225(55 \%)$ versus $101(50 \%)$ patients, and severe in $68(17 \%)$ versus $26(13 \%)$ patients. Serious adverse events were reported in $21(10 \%)$ and $24(12 \%)$ patients in the degarelix 240/80 and degarelix $240 / 160$ groups compared to 28 (14\%) patients in the leuprolide group. The number of patients terminating the study due to adverse events was comparable in the three treatment arms: $15(7 \%)$ in the degarelix 240/80 group, $19(9 \%)$ in the degarelix 240/160 group, and $12(6 \%)$ in the leuprolide group.

The most frequently reported adverse events in both groups were hot flashes (26\% in the pooled degarelix group vs $21 \%$ in the leuprolide group). Patients treated with degarelix reported statistically significant more injection site reactions than patients treated with leuprolide $(40 \%$ in the pooled degarelix group vs $<1 \%$ in the leuprolide group; $\mathrm{p}<0.001$ ). These injection site reactions included pain, erythema, swelling, induration, and nodule. They were the reason for discontinuation in five patients $(1 \%)$ treated with degarelix although they occurred predominantly after the first injection und were documented to be mild or moderate in intensity.

In 18 patients (4\%) treated with degarelix, chills were an adverse event compared to no such event in the leuprolide group $(\mathrm{p}<0.01)$. Further significant differences between the treatment groups were arthralgia (4\% in the pooled degarelix group vs $9 \%$ in the leuprolide group; $p<0.05)$ and urinary tract infections $(3 \%$ in the pooled degarelix group vs $9 \%$ leuprolide group; $\mathrm{p}<0.01)$.

In each degarelix group, five patients ( $2 \%$ ) died compared to nine patients (4\%) in the leuprolide group. None of the death was considered to be treatment-related. ${ }^{14}$

\section{Conclusions}

The administration of the GnRH antagonist degarelix is associated with a rapid, profound, and sustained suppression of testosterone in patients with prostate cancer. Results from the recently published randomized, open-label, three-arm phase III study showed that degarelix is not inferior to leuprolide at maintaining testosterone suppression over a one-year treatment period and degarelix was able to produce a faster testosterone suppression and PSA decline than leuprolide. ${ }^{14}$

In the last ten years, degarelix has run through various phase I and II trials and dose-finding was a major goal of these trials. ${ }^{22}$ As a result from these trials an initial dose of $240 \mathrm{mg}$ seems to be the best dose to achieve a clinically relevant testosterone suppression in more than $90 \%$ of patients within three days and in more than $95 \%$ of patients after one month. ${ }^{14,21}$ A maintenance dose of $80 \mathrm{mg}$ and $160 \mathrm{mg}$ degarelix every four weeks resulted in a profound and sustained testosterone suppression. ${ }^{14,21}$ In December 2008, degarelix at a dose of $240 \mathrm{mg}$ sc followed by $80 \mathrm{mg}$ sc every month has been approved for the treatment of advanced prostate cancer by the US Food and Drug Administration (FDA) and its approval by the European Medicines Agency (EMEA) has been recommended. ${ }^{23}$ However, it is a clear disadvantage that degarelix is currently only available as a one-month formulation.

Degarelix has an immediate onset of action with no need for clinical flare protection with an antiandrogen as required in some patients treated with GnRH agonists. ${ }^{24}$ This kind of action of degarelix might offer advantages especially in patients with advanced prostate cancer and a higher risk for symptoms associated with clinical flare. Testosterone surge begins two to three days after administration of GnRH agonists. ${ }^{24}$ Theoretically, the median testosterone can increase by $100 \%$. In the phase III trial it was demonstrated that median testosterone increased by $65 \%{ }^{14}$ This may be 
associated with exacerbation of symptoms from prostate cancer. The symptoms may include bone pain, spinal cord compression, bladder outlet obstruction, cardiovascular problems, and so forth. However, there are wide discrepancies in reports of the frequency and severity of acute clinical progression or clinical flare that might result from the testosterone surge. The use of GnRH agonists for patients with metastatic prostate cancer can be associated with clinical flare in approximately $10 \%$ of the patients. ${ }^{24}$ In contrast, patients with non-metastatic prostate cancer have very little risk for clinical flare. Antiandrogen therapy reduces, but does not totally eliminate, clinical flare in patients at high risk for this scenario. ${ }^{24}$ In the phase III trial it was voluntarily allowed to give bicalutamide for prevention of clinical flare. However, only $11 \%$ patients received bicalutamide and no patient of the entire leuprolide group had documented clinical flare. ${ }^{14}$

Abarelix (Plenaxis ${ }^{\circledR}$; Praecis Pharmaceuticals, Cambridge, MA, USA) was the first GnRH antagonist to be approved (in 2003) by the FDA for patients with advanced, symptomatic prostate cancer who cannot have or refuse other treatments for prostate cancer, such as other hormone treatments or surgery to remove the testicles. ${ }^{25}$ The reason for this restriction was that the administration of abarelix could be associated with acute systemic allergic reaction. In 15/1397 (1.1\%) patients treated with abarelix this symptom was evident. In 14/15 patients the symptoms occurred within eight minutes of injection. In 2005, Praecis Pharmaceuticals voluntarily discontinued promotional activities relating to abarelix in the US and the sale of abarelix for patients not currently on therapy. ${ }^{25}$ However, in 2005 the drug was approved in Germany but not in other European countries. Since 2008, abarelix is available on the German market under the license of Speciality European Pharma. ${ }^{26}$ A systemic allergic reaction was not reported in any of the degarelix studies. ${ }^{14,20,21}$ Otherwise, in the randomized phase III trial $4 \%$ of the degarelix-treated patients reported chills versus none of the patients treated with leuprolide. ${ }^{14}$ These chills were neither discussed nor explained by the authors. Therefore, further reports on degarelix with long-term follow-up on efficacy and safety - especially concerning the allergic potential - are mandatory.

Also, it should be realized that $40 \%$ of patients experienced injection site reactions of degarelix compared to $<1 \%$ at the im injection site of leuprolide. ${ }^{14}$ Why is the application of degarelix so painful? One explanation could be that the injected volume is rather high. In fact, $2 \times 3 \mathrm{ml}$ are injected to apply the initial dose of $240 \mathrm{mg}$ degarelix.

If patients are diagnosed with prostate cancer the question today is: who needs androgen deprivation therapy? In a population-based cohort study of 19,271 patients older than 65 years (median age 77 years) having prostate cancer and treated with androgen deprivation therapy $(7,867$ patients $)$ or conservative management (11,047 patients) were studied. ${ }^{27}$ Patients had a T1 disease in 49.8\% (androgen deprivation group) compared to $64.2 \%$ (conservative management group) and the tumor was moderately and poorly differentiated in $65 \%$ and $34.2 \%$ (androgen deprivation group) compared to $83.7 \%$ and $14.2 \%$ (conservative management group). It was demonstrated that 10-year cancer-specific survival in patients receiving androgen deprivation therapy was $80.1 \%$ compared to $82.6 \%$ (Hazard ratio [HR]: 1.17, 95\% confidence interval [CI]: 1.03-1.33) in patients receiving conservative management (defined as not receiving operative therapy, radiotherapy or androgen deprivation therapy within 180 during the first days from diagnosis). ${ }^{27}$ Ten-year overall survival was $30.2 \%$ (androgen deprivation group) compared to 30.3\% (conservative management group) and median overall survival was 82 months in both groups. However, in patients with poorly differentiated prostate cancer it was shown that cancer specific survival was better in patients receiving androgen deprivation therapy (59.8\% vs $54.3 \%$, HR: $0.84,95 \%$ CI: $0.7-1$; $\mathrm{p}=0.049$ ). It is noteworthy that $75 \%$ of all patients received androgen deprivation therapy for a minimum of 18 months and $50 \%$ of patients for longer than 30 months. ${ }^{27}$

Not only the efficacy of androgen deprivation therapy in terms of survival needs to be questioned but also possible adverse events. Androgen deprivation therapy itself is potentially associated with several adverse events. These include hot flashes, osteoporosis, loss of libido or impotence, psychological effects such as depression, memory difficulties or emotional lability, and others. ${ }^{28-32}$

Diabetes and cardiovascular disease are especially unwanted adverse events among older patients. However, there is growing evidence that androgen deprivation therapy is associated with an increased risk of cardiovascular disease and diabetes. ${ }^{28}$ In an observational study of a populationbased cohort of 73,196 patients older than 65 years (mean age 74.2 years, standard deviation 5.8 years) having prostate cancer were investigated. The endpoints incident diabetes, coronary heart disease, myocardial infarction, and sudden cardiac death occurred in $10.9 \%, 25.3 \%, 5.4 \%$, and $4.5 \%$ of all cases. A total of $36.3 \%$ of patients received a GnRH agonist for a mean of $40 \%$ of time from diagnosis to censoring. This use of a GnRH agonist was associated with an increased risk of incident diabetes (adjusted HR: 1.44; P < 0.001), coronary heart disease (adjusted HR: 1.16; $\mathrm{p}<0.001$ ), myocardial infarction (adjusted HR: 1.11; $<<0.03$ ), and sudden cardiac 
death (adjusted HR: 1.16; p < 0.003). In 6.9\% of patients an orchiectomy was performed for androgen deprivation therapy. It is noteworthy that in these patients a greater risk for diabetes (adjusted HR: 1.34; $\mathrm{p}<0.001$ ) compared to no therapy was also found but this was not the case for coronary heart disease (adjusted HR 0.99; $p=0.74$ ), myocardial infarction (adjusted HR: 0.94; $\mathrm{p}=0.44$ ), and sudden cardiac death (adjusted HR: $1.91 ; \mathrm{p}=0.85$ ). ${ }^{28}$

In summary, degarelix is associated with a rapid, profound, and sustained suppression of testosterone in patients with prostate cancer. Antiandrogens to prevent testosterone surge and prevent clinical flare are not required. This may reduce costs and adverse events from the antiandrogen. Thus, a GnRH antagonist rather than a GnRH agonist may be used in patients with high tumor burden and/or acute problems such as spinal cord compression. In contrast to other GnRH antagonists degarelix was not associated with systemic allergy reaction. In the phase III trial, however, two adverse events occurred more often with degarelix compared to leurolide: injection site reactions $(40 \%$ vs $<1 \%)$ and unexplained chills following the application degarelix ( $4 \%$ vs $0 \%$ ). Beside adverse events there is currently no threemonth formulation of degarelix available. A three-month interval for the application of $\mathrm{GnRH}$ agonists is convenient for the patient and currently the most often applied regimen. The phase III trial by Klotz and colleagues was not blinded and all patients "in whom androgen deprivation therapy was indicated" were included. What we don't have for degarelix is data on cancer-specific survival and overall survival as well as any data in patients undergoing intermittent androgen deprivation therapy and complete androgen blockade. Finally, the average monthly cost of degarelix treatment is probably comparable to other hormone treatments for prostate cancer; in other words, degarelix is not cheaper. Therefore, the potential role of degarelix within a discussion about the indication for androgen deprivation therapy with regard to efficacy, adverse events, and costs remains unclear and could be limited.

\section{Disclosure}

The authors report no conflicts of interest in this work.

\section{References}

1. Jemal A, Siegel R, Ward E, et al. Cancer statistics, 2008. CA Cancer J Clin. 2008;58(2):71-96.

2. Wilt TJ, MacDonald R, Rutks I, Shamliyan TA, Taylor BC, Kane RL. Systematic review: comparative effectiveness and harms of treatments for clinically localized prostate cancer. Ann Intern Med. 2008;148(6): $435-448$.
3. Klotz L. Active surveillance for prostate cancer: trials and tribulations. World J Urol. 2008;26(5):437-442.

4. Antonarakis ES, Blackford AL, Garrett-Mayer E, Eisenberger MA. Survival in men with nonmetastatic prostate cancer treated with hormone therapy: a quantitative systematic review. J Clin Oncol. 2007; 25(31):4998-5008.

5. Thompson I, Thrasher JB, Aus G, et al; AUA Prostate Cancer Clinical Guideline Update Panel. Guideline for the management of clinically localized prostate cancer: 2007 update. J Urol. 2007;177(6): 2106-2131.

6. Loblaw DA, Virgo KS, Nam R, et al; American Society of Clinical Oncology. Initial hormonal management of androgen-sensitive metastatic, recurrent, or progressive prostate cancer: 2006 update of an American Society of Clinical Oncology practice guideline. J Clin Oncol. 2007;25(12):1596-1605.

7. Huggins C, Stevens RE Jr, Hodges CV. Studies on prostate cancer. II. The effect of castration on advanced carcinoma of the prostate gland. Arch Surg. 1941;43:209-223.

8. Montironi R, Magi-Galluzzi C, Muzzonigro G, Prete E, Polito M, Fabris G. Effects of combination endocrine treatment on normal prostate, prostatic intraepithelial neoplasia, and prostatic adenocarcinoma. J Clin Pathol. 1994;47(10):906-913.

9. Castellón E, Clementi M, Hitschfeld C, et al. Effect of leuprolide and cetrorelix on cell growth, apoptosis, and GnRH receptor expression in primary cell cultures from human prostate carcinoma. Cancer Invest. 2006;24(3):261-268.

10. Seidenfeld J, Samson DJ, Hasselblad V, et al. Single-therapy androgen suppression in men with advanced prostate cancer: a systematic review and meta-analysis. Ann Intern Med. 2000;132(7):566-577.

11. McLeod DG. Hormonal therapy: historical perspective to future directions. Urology. 2003;61(2 Suppl 1):3-7.

12. Cook T, Sheridan WP. Development of GnRH antagonists for prostate cancer: new approaches to treatment. Oncologist. 2000;5(2): $162-168$.

13. Huirne JA, Lambalk CB. Gonadotropin-releasing-hormone-receptor antagonists. Lancet. 2001;358(9295):1793-1803.

14. Klotz L, Boccon-Gibod L, Shore ND, et al. The efficacy and safety of degarelix: a 12-month, comparative, randomized, open-label, parallel-group phase III study in patients with prostate cancer. $B J U$ Int. 2008;102(11):1531-1538.

15. Jiang G, Stalewski J, Galyean R, et al. GnRH antagonists: a new generation of long acting analogues incorporating p-Ureido-phenylalanines at position 5 and 6. J Med Chem. 2001;44(3):453-467.

16. Broqua P, Riviere PJM, Conn PM, Rivier JE, Aubert ML, Junien JL. Pharmacological profile of a new, potent and long-acting gonadotropinreleasing hormone antagonist: degarelix. J Pharmacol Exp Ther. 2002;301(1):95-102.

17. Schwach G, Oudry N, Delhomme S, Luck M, Lindner H, Gurny R. Biogradable microparticles for sustained release of a new GnRH antagonist - part I: screening commercial PLGA and formulation technologies. Eur J Pharm Biophar. 2003;56(3):327-336.

18. Weston PMT, Hammonds J, Vaughton Olesen TK, Jensen JK, Eskerod O, Persson BE. Degarelix; a novel GnRH antagonist tested in a multicentre, randomized dose-finding study in prostate cancer patients. BJU Int. 2004;94(Suppl 2):57.

19. Tammela T, Iversen P, Johansson J, Persson B, Jensen, Olsen T, Degarelix Study group. Degarelix; a phase II multicenter, randomised dose-escalating study testing a novel GnRH receptor blocker in prostate cancer patients. Eur Urol Suppl. 2005;4(3):228.

20. Gittelman M, Pommerville PJ, Persson BE, Jensen JK, Olesen TK; Degarelix Study Group. A 1-year, open label, randomized phase II dose finding study of degarelix for the treatment of prostate cancer in North America. J Urol. 2008;180(5):1986-1992.

21. Van Poppel H, Tombal B, de la Rosette JJ, et al. Degarelix: a novel gonadotropin-releasing hormone $(\mathrm{GnRH})$ receptor blocker-results from a 1 -yr, multicentre, randomised, phase 2 dosage-finding study in the treatment of prostate cancer. Eur Urol. 2008;54(4):805-813. 
22. Doehn C, Sommerauer M, Jocham D. Drug evaluation: Degarelix - a potential new therapy for prostate cancer. IDrugs. 2006;9(8):565-572.

23. US Food and Drug Administration. Degarelix. Dec 29, 2008. Accessed on Feb 14, 2009. Available from: http://www.fda.gov/cder/Offices/ OODP/whatsnew/Degarelix.htm.

24. Bubley GJ. Is the flare phenomenon clinically significant? Urology. 2001;58(2 Suppl 1):5-9.

25. US Food and Drug Administration. Plenaxis (abarelix for injectable suspension) Nov 25, 2003. Accessed on Feb 14, 2009. Available from: http://www.fda.gov/cder/drug/infopage/plenaxis/default.htm.

26. Speciality European Pharma. 2009. Accessed on Feb 14, 2009. Available from: http://www.specialityeuropeanpharma.com.

27. Lu-Yao GL, Albertsen PC, Moore DF, et al. Survival following primary androgen deprivation therapy among men with localized prostate cancer. JAMA. 2008;300(2):173-181.
28. Keating NL, O’Malley AJ, Smith MR. Diabetes and cardiovascular disease during androgen deprivation therapy for prostate cancer. J Clin Oncol. 2006;24(27):4448-4456.

29. Potosky AL, Knopf K, Clegg LX, et al. Quality-of-life outcomes after primary androgen deprivation therapy: results from the Prostate Cancer Outcomes Study. J Clin Oncol. 2001;19(17):3750-3757.

30. Sharifi N, Gulley JL, Dahut WL. Androgen deprivation therapy for prostate cancer. JAMA. 2005;294(2):238-244.

31. Mottet N, Prayer-Galetti T, Hammerer P, Kattan MW, Tunn U. Optimizing outcomes and quality of life in the hormonal treatment of prostate cancer. BJU Int. 2006;98(1):20-27.

32. Saigal CS, Gore JL, Krupski TL, Hanley J, Schonlau M, Litwin MS; And the Urologic Diseases in America Project. Androgen deprivation therapy increases cardiovascular morbidity in men with prostate cancer. Cancer. 2007;110(7):1493-1500. 
